"Volume 10, No. 2, Desember 2016"

\title{
GIJZELING; METODE PENYELESAIAN KREDIT MACET HUKUM PERDATA
}

\section{Oleh :}

\section{Subaidi}

Fakultas Ekonomi dan Bisnis Islam IAI Ibrahimy Situbondo subaidishalli@yahoo.co.id

\begin{abstract}
Bad Creditisa problem loan or a non-performing loanthat for some reasons a customer reneging on promises to pay off debts after due dateso there is a delay or not paid altogether so that arose a bad credit or a bad debt.The existence of bank can not be separated from risk in the banking world. So it is necessary to minimize them by keeping the quality of loans in a case of nonperforming loans.

Gijzeling is an effort to press the case of a bad credit which is the act to a physical or an agency of a debtor by entering them into prisonso that they loses the right to freedom.

This act is expected to be a deterrent effect, because they feel uncomfortable with any restriction in action, so that the debtor decide to immediately pay or pay off that debts
\end{abstract}

Keywords: Kredit macet, debitur, debitur, dan risiko nasabah

\section{A. Pendahuluan}

Transaksi hutang piutang dapat terlaksana dengan kerelaan dan amal shalih. Islam mengakui perlunya hutang piutang untuk memenuhi kebutuhan debitur, karena seruan perlunya hal ini ditunjukkan dengan adanya anjuran untuk bersikap sosial yang penuh kasih sayang.

Cara lain dalam penyelesaian kredit macet yang bisa dilakukan adalah dengan menjual seluruh perusahaan kepada pihak lain atau disebut dengan Leveraged Buy Out (LBO) pinjaman 100 persen, yang kemudian bank dapat mengalihkan hutang yang macet kepada pemilik yang baru, bank mengharapkan perusahaan berjalan lancar kembali pada waktu yang dituangkan dalam proyeksi keuangan kredit yang akan cair kembali dan diperoleh kembali oleh pihak bank.

Pada umumnya, bank yang mempunyai kredit macet dalam keadaan terjepit sehingga di dalam negosiasi pengambilalihan perusahaan dengan kredit macet oleh pihak lain, bank cenderung ditekan untuk memberikan konsesi-konsesi dan fasilitas dalam bentuk penghapusan 
sebagian besar kredit dan bunga yang sudah menumpuk, penjadwalan kembali pembayaran bunga dan cicilan utang pokok, memberikan tenggang waktu yang panjang mengenakan bunga yang amat indah untuk jangka waktu yang lama dan seterusnya bank tentu tidak rela dan ini membuat negosiasi menjadi alat.

Kredit dalam hukum perdata merupakan perjanjian pinjam meminjam uang antara bank sebagai kreditur dengan nasabah sebagai debitur. Dalam perjanjian, bank sebagai pemberi kredit percaya terhadap nasabahnya dalam jangka waktu yang telah disepakati uang yang dipinjamnya akan dikembalikan lunas. Hal ini tentunya tidak jauh berbeda dengan pengertian hutang dalam hukum Islam yang berarti memberikan sesuatu pada seseorang dengan perjanjian dia akan membayarnya yang sama dengan itu.

Oleh karenanya kreditur dari bank milik Negara, bank swasta atau perorangan dapat mengajukan paksa badan yaitu upaya paksa tidak langsung dengan memasukkan debitur yang beriktikat tidak baik ke dalam rumah tahanan Negara yang ditetapkan pengadilan untuk memaksa yang bersangkutan memenuhi kewajibannya membayar hutang.

\section{B. Pembahasan}

\section{Penyelesaian Kredit Macet}

Tidak seluruh debitur dapat mengembalikan kredit tepat waktu sesuai dengan yang dijanjikan. Seorang debitur yang dalam keadaan terpaksa tidak mampu membayar hutangnya selama $2 \times 1,5$ tahun atau 3 tahun kesempatan. Selama 3 tahun dimaksudkan agar debitur mampu memperbaiki kondisi perusahaannya yang goncang tersebut, akan tetapi bila dalam tenggang waktu itu tidak ada perubahan, maka kreditur akan dinyatakan pailit.

Secara operasional penanganan penyelesaian kredit dapat ditempuh melalui beberapa cara yaitu: pertama, penjadwalan kembali untuk melakukan perubahan terhadap beberapa syarat perjanjian kredit yang berkenaan dengan jadwal pembayaran kembali atau jangka waktu kredit termasuk masa tenggang dan perubahan jumlah angsuran dengan penambahan kredit.

Kedua, Persyaratan kembali melakukan atas sebagian atau seluruh syarat-syarat perjanjian yang tidak terbatas hanya kepada perubahan jadwal angsuran atau jangka waktu kredit saja. Namun perubahan kredit tersebut tanpa memberikan tambahan kredit atau tanpa melakukan konversi atas seluruh atau sebagian dari kredit menjadi equity perusahaan. Ketiga, Penataan kembali berupa melakukan perubahan 
syarat-syarat kredit berupa pemberian tambahan kredit atau melakukan konversi atas seluruh atau sebagian kredit menjadi perusahaan yang dilakukan dengan atau tanpa rescheduling dan atau reconditioning.

Di dalam UU No. 7 tahun 1992 dikenal dengan sistem penyelamatan kredit macet sebagaimana diatur dalam pasal 17 ayat c berbunyi:

"Bank umum dapat pula melakukan kegiatan penyertaan modal sementara akibat mengatasi kegagalan kredit dengan syarat harus menarik kembali penyertaannya, dengan memenuhi ketentuan yang ditetapkan oleh Bank Indonesia"

Berdasarkan ketentuan tersebut, maka bank akan memasukkan modal atau memasukkan untuk sementara kredit yang macet tersebut sebagai tanda penyertaan modal suatu perusahaan. Jika nanti perusahaan tersebut telah sehat kembali maka bank akan segera mungkin menarik kembali kredit macet itu (dan sekaligus mengakhiri penyertaannya dalam perusahaan tersebut). ${ }^{1}$

Cara lain dalam penyelesaian kredit macet yang bisa dilakukan adalah dengan menjual seluruh perusahaan kepada pihak lain atau disebut dengan Leveraged Buy Out (LBO) pinjaman 100 persen, yang kemudian bank dapat mengalihkan hutang yang macet kepada pemilik yang baru, bank mengharapkan perusahaan berjalan lancar kembali pada waktu yang dituangkan dalam proyeksi keuangan kredit yang akan cair kembali dan diperoleh kembali oleh pihak bank.

Pada umumnya, bank yang mempunyai kredit macet dalam keadaan terjepit sehingga di dalam negosiasi pengambilalihan perusahaan dengan kredit macet oleh pihak lain, bank cenderung ditekan untuk memberikan konsesi-konsesi dan fasilitas dalam bentuk penghapusan sebagian besar kredit dan bunga yang sudah menumpuk, penjadwalan kembali pembayaran bunga dan cicilan utang pokok, memberikan tanggung waktu yang panjang mengenakan bunga yang amat indah untuk jangka waktu yang lama dan seterusnya bank tentu tidak rela dan ini membuat negosiasi menjadi alat. ${ }^{2}$

Bila melalui berbunga usaha tersebut diatas ternyata masalah kredit tidak dapat diselesaikan, atau bank beranggapan bahwa jalan tersebut tidak akan menghasilkan sesuatu yang diharapkan, maka jalan

1 Zainal Asikin, Pokok Hukum Perbankan di Indonesia, (Jakarta : Gema Insani Press, 2010), hlm. 64-66

${ }^{2}$ Kwik Kian Gie, Praktik Bisnis dan Orientasi Ekonomi Indonesia, (Jakarta : Kencana, 2006), hlm. 111 - 112 
terakhir yang dilakukan adalah dengan menyerahkan menyelesaikan kepada pihak ketiga melalui beberapa upaya hukum, diantaranya:

Pertama, melalui Badan Urusan Piutang dan Lelang Negara (BUPLN). Bagi kredit macet yang menyangkut bank milik Negara, biasanya kredit yang telah macet (dan telah diupayakan penagihan atau penyelesaian secara kekeluargaan tetapi tidak berhasil), maka bank akan menyerahkan penyelesaiannya melalui BUPLN untuk selanjutnya akan melakukan pelelangan atau penjualan benda jaminan, sebab apabila bank telah memperoleh "kuasa menjual" maka ia dapat menjual harta jamianan tersebut secara dibawah tangan.

Kedua, melalui Arbitrase. Lembaga ini sebenarnya telah lama dikenal dalam khazanah hukum yaitu Undang-undang No. 14 tahun 1970 jo pasal 377 HIR, Reglement op de Bungerijke Rechts or dering (ru) stb 1847 No. 52 Di dalam perjanjian kredit perbankan, bank dan nasabahnya dapat menuangkan klausul arbitrase yang berisi bahwa jika terjadi sengketa antara bank dan nasabahnya (misalnya kredit macet), maka mereka akan menyelesaikan persoalannya melalui perantara lembaga arbitrase.

Ketiga, melalui pengadilan. Apabila terjadi kredit macet, maka penyelesaiannya dapat juga dilakukan melalui pengadilan. Proses legitasi merupakan langkah terpaksa yang dilakukan bank apabila debitur menunjukkan iktikat tidak baik yang sengaja menyembunyikan harta bendanya yang masih cukup banyak untuk melunasi kreditnya. ${ }^{3}$

\section{Pandangan Umum tentang Gijzeling \\ a. Pengertian Gijzeling}

Gijzeling diterjemahkan dengan istilah penyanderaan diterapkan hanya jika debitur sebagai pihak yang melaksanakan putusan pengadilan tidak memiliki barang lagi yang bisa dijual untuk menjalankan putusan pengadilan.

Namun setelah dikeluarkan peraturan Mahkamah Agung RI Nomor 1 tahun 2000 tanggal 30 Juni 2000, gijzeling yang penerjemahannya disempurnakan menjadi paksa badan menyangkut pengertian upaya paksa tidak langsung dengan memasukkan seorang debitur yang beriktikat tidak baik ke dalam rumah tahanan Negara yang ditetapkan pengadilan untuk memaksa yang bersangkutan memenuhi kewajibannya. ${ }^{4}$

${ }^{3}$ Zainal Asikin, Pokok Hukum Perbankan di Indonesia, (Jakarta : Gema Insani Press, 2010), hlm. 64-68.

${ }^{4}$ Suharmo, Aspek-aspek Hukum Perkreditan pada Bank, (Jakarta : PT. Raja Grafindo

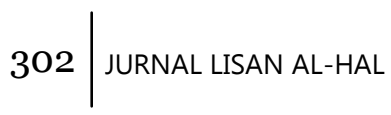


Dalam praktiknya, tidak jarang terjadi bahwa debitur yang dikalahkan atau tahu akan dikalahkan dalam proses pengadilan, sehingga jauh sebelumnya telah mengalihkan harta kekayaannya terhadap saudara atau orang lain dengan maksud menghindari harta kekayaan dari penyitaan. Dengan demikian maka secara formil debitur tampaknya sebagai orang miskin, tetapi secara materiil tidaklah dapat dikatakan demikian. Mengingat hal semacam itu lembaga sandera perlu kiranya dipertahankan demi kepentingan debitur dengan catatan bahwa penerapannya harus berhati-hati. ${ }^{5}$

Dari pengertian ini dapat diketahui bahwa unsur-unsur gijzeling yaitu: Pertama, upaya tidak langsung, artinya suatu tindakan terhadap fisik atau badan seorang debitur dengan cara memasukkan ke dalam rumah tahanan Negara, sehingga orang tersebut kehilangan hak kebebasannya. Tindakan ini diharapkan dapat menimbulkan efek jera. Karena merasa tidak nyaman dengan adanya pembatasan dalam hal bertindak, sehingga debitur beriktikat untuk segera membayar atau melunasi hutangnya.

Kedua, Seorang debitur adalah orang yang berhutang yang menandatangani perjanjian, kredit atau pengakuan hutang bila yang berhutang perorangan, jika debitur berbentuk koorporase seperti Perseroan Terbatas (PT) atau koperasi atau badan usaha lainnya, maka debitur yang diajukan untuk paksa badan adalah direksinya sesuai dengan pasal 85 dan 90 Undang-undang No. 1 tahun 1995 tentang Perseroan Terbatas.

Ketiga, debitur berniat tidak baik atau debitur nakal adalah debitur termasuk penanggung atau peminjam hutang yang mampu tetapi tidak mau memenuhi kewajibannya untuk membayar hutangnya. Indikasi atau kreteria debitur nakal ini dapat dilihat debitur atau penjamin atau penanggung yang mempunyai harta kekayaan seperti rumah mewah, kendaraan mewah, dan memiliki asset-asset diberbagai tempat dan memiliki usaha lain (diluar jangkauan).

Keempat, Untuk memasukkan seorang debitur ke dalam rumah tahanan Negara harus seizin dari ketua Pengadilan Negeri berupa penetapan ketua Pengadilan Negeri untuk melaksanakan keputusan pengadilan yang sudah tetap atau keputusan belum memiliki kekuatan hukum tetap, tetapi diputuskan serta-merta yang dalam keputusan

Persada, 2009), hlm. 418 - 419.

5 Sudikno Mertokusumo, Hukum Acara Perdata Indonesia, (Surabaya : CV Putra Media Nusantara \& ITS Press, 2009), hlm. 222. 
tersebut dikabulkannya tuntutan paksa badan.

\section{b. Dasar-dasar Hukum dan Ketentuan Gijzeling}

Lembaga-lembaga sandera di Indonesia sudah diatur dalam beberapa ketentuan, antara lain adalah Herziene Indonesisch Reglement (HIR), dari pasal 209 sampai pasal 224. Pasal 209 (1) jika tidak ada atau cukup dasar untuk memastikan perjalanan keputusan,maka ketua Pengadilan Negeri atas permintaan pihak yang menang dengan lisan atau dengan surat, memberi perintah dengan surat pada orang yang berkuasa untuk menjalankan surat sita. Supaya orang yang berhutang itu disandera (di-Gijzel). (2) lamanya orang berhutang dapat disandera menurut pasal berikut, harus disebut dalam perintah itu.

Selain dari cara-cara eksekusi keputusan hakim dengan jalan menyita dan menjual lelang barang milik pihak yang kalah, apalagi ia tidak mau memenuhi keputusan hakim, ada lagi cara lain dengan jalan menyanderakan, yaitu menyuruh tahan pihak yang kalah di dalam rumah lembaga permasyarakatan dengan maksud untuk memaksanya supaya memenuhi keputusan hakim.

Pada pasal 224 HIR juga menerangkan, bahwa surat-surat yang dianggap mempunyai kekuatan yang pasti dieksekusi seperti surat keputusan hakim yaitu: Surat untuk memakai hipotik dan surat hutang yang dilakukan dihadapan Notaris (akte notaris) yang kepalanya perkataan-perkataan dahulu "atas nama Raja" kemudian berturut-turut diubah menjadi "atas nama Republik Indonesia, atas nama undangundang", dan sekarang berdasarkan pasal 4 undang-undang pokok kehakiman no. 14 / 1970 menjadi "Demi keadilan berdasarkan ketuhanan yang maha Esa".

Apabila surat-surat tersebut diatas itu tidak ditepati dengan jalan damai, maka akan dijalankan seperti keputusan hakim biasa, yaitu dilangsungkan dengan perintah dan pimpinan Ketua Pengadilan Negeri yang dalam daerah hukumnya orang yang berhutang itu diam atau tinggal atau memilih sebagai tempat tinggalnya, akan tetapi mengenai paksaan badan (sandera: gijzelink) hanya dapat dilakukan apabila sudah diizinkan dengan keputusan Pengadilan Negeri. ${ }^{6}$

\section{Syarat-syarat Mengajukan Paksa Badan}

Kreditur dari bank milik Negara atau bank swasta atau perorangan dapat mengajukan paksa badan kepada debitur yang memenuhi syarat

${ }^{6}$ R. Soesilo, RIB/HIR dengan Penjelasannya, (Bogor : Politera,1984), hlm. 153-160.

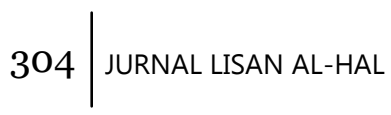


paksa badan pengadilan yaitu: Pertama, debitur yang beriktikad tidak baik atau nakal yang mempunyai hutang sekurang-kurangnya 1 miliar rupiah (pokok dan bunga) berdasarkan perjanjian kredit atau pengakuan hutang. ${ }^{7}$ Kedua, debitur mempunyai kemampuan untuk menyelesaikan hutang tetapi tidak menunjukkan i'tikad baik untuk menyelesaikan. ${ }^{8}$

Ketiga, seorang penjamin atau penanggung yang menjamin hutang debitur berdasakan perjanjian penjamin yang menjamin hutang debitur sekurang-kurangnya 1 miliar rupiah (pokok dan bunga). Seorang penjamin bisa orang perorangan atau pribadi maka pribadi yang bersangkutan yang diajukan paksa badan dan jika yang menjadi penjamin atau penanggung berupa Corporate (badan usaha) maka yang diajukan paksa badan adalah direksi dari badan usaha yang bersangkutan.

Keempat, seorang atau para ahli waris juga dapat diajukan paksa badan jika orang keturunan sebagai ahli waris telah menerima warisan dari orang tuanya sebagai debitur yang tidak membayar hutangnya. Kelima, hutang debitur sudah tergolong macet dan perjanjian kredit telah jatuh tempo. Keenam, kreditur atau bank yang mengajukan paksa badan menanggung biaya selama debitur atau penjamin atau penanggung menjalani paksa badan tetapi debitur dapat memperbaiki kehidupannya atas biaya sendiri. Ketujuh, Paksa badan ditetapkan enam bulan lamanya dan dapat diperpanjang enam bulan dengan keseluruhan maksimal tiga tahun. Kedelapan, debitur atau penjamin atau penanggung yang sudah berusia 75 tahun keatas tidak dapat diajukan paksa badan.

\section{Prosedur Permohonan Paksa Badan}

Kreditur atau bank yang akan mengajukan upaya paksa badan terhadap debitur atau penjamin atau penanggung hutang harus menempuh prosedur hukum. Kreditur tidak boleh begitu saja melakukan paksa badan atau sandera sendiri yang dapat dinilai sebagai perbuatan main hakim sendiri. Untuk mengajukan paksa badan terhadap debitur atau penjamin hutang harus berdasarkan keputusan pengadilan yang tetap atau keputusan pengadilan yang belum tetap, tetapi keputusan tersebut dapat dilaksanakan serta-merta atau berdasarkan akta pengakuan hutang nota riil sebagaimana dimaksud dalam pasal 224 HIR.

Pasal 218 HIR ayat 6 menentukan bahwa paksa badan hanya dapat diterapkan berdasarkan keputusan pengadilan yang telah mempunyai

7 Sutarno, Aspek-aspek Hukum Perkreditan pada Bank, (Bandung : PT Refika Aditama, 2002), hlm. 334.

8 Ibid, hlm. 419 
kekuatan hukum tetap atau putusan yang belum memiliki putusan hukum tetap, tetapi keputusan tersebut oleh hakim diputuskan dengan serta merta. Suatu putusan yang belum memiliki kekuatan hukum tetap dan tidak serta-merta, paksa badan belum dapat dilaksanakan.

Oleh karena itu untuk mengajukan paksa badan kepada debitur atau penjamin hutang, kreditur harus menempuh prosedur hukum dengan mengajukan gugatan kepada debitur melalui Pengadilan Negeri untuk memperoleh dasar hukum pengajuan paksa badan dengan cara pengajuan paksa badan ke Pengadilan Negeri berdasarkan kepada proses akta pengakuan hutang seperti di maksud dalam pasal $224 \mathrm{HIR}$.

Bagi kreditur yang melakukan pengikatan kredit selain membuat perjanjian kredit juga membuat akta pengakuan hutang nota riil maka proses akta pengakuan hutang tersebut dapat digunakan sebagai dasar hukum mengajukan gugatan melalui Pengadilan Negeri. Menurut pasal 224 HIR menentukan bahwa akta pengakuan hutang yang dibuat oleh dan dihadapan notaris yang berkepala 'demi keadilan berdasarkan ketuhanan yang maha Esa', mempunyai kekuatan hukum yang sama dengan keputusan pengadilan yang tetap, karena proses akta pengakuan hutang oleh undang-undang diberikan kekuatan hukum yang sama dengan keputusan pengadilan yang tetap, maka oleh pasal 7 Peraturan Mahkamah Agung RI. Nomor 1 tahun 2000 tanggal 30 Juni 2000, dimungkinkan menggunakan akta pengakuan hutang sebagai dasar hukum mengajukan permohonan paksa badan bagi para debitur yang tidak melunasi hutangnya, padahal debitur tersebut mempunyai kemampuan untuk membayar atau melunasinya. Pasal 7 tersebut menentukan kewajiban debitur yang didasarkan atas pengakuan hutang sebagaimana diatur dalam pasal 224 HIR, paksa badan dapat diajukan tersendiri dan dilaksanakan berdasarkan penetapan Ketua Pengadilan Negeri.

Bagi kreditur yang memiliki grose akta pengakuan hutang nota riil yang berkepala 'demi keadilan berdasarkan ketuhanan yang maha Esa', dapat menggunakan grose akta pengakuan hutang tersebut untuk langsung mengajukan permohonan paksa badan kepada debitur atau penjamin atau penanggung melalui Pengadilan Negeri dimana debitur atau penjamin atau penanggung berdomisili. Jadi dengan memiliki grose akta pengakuan hutang kreditur tidak perlu mengajukan gugatan kepada debitur atau penjamin atau penanggung sebagai dasar hukum permohonan paksa badan.

Permohonan kreditur untuk mengajukan paksa badan kepada debitur atau penjamin berdasarkan grose akta pengakuan hutang tersebut, Ketua Pengadilan Negeri akan mengeluarkan penetapan paksa 
badan dan memerintahkan kepada juru sita untuk mengeksekusi paksa badan terhadap debitur atau penjaminnya.

Cara ini cukup efisien dan cepat, menguntungkan bank, asalkan kreditur memiliki grose akta pengakuan hutang yang bisa dibuat bersamaan dengan perjanjian kredit ditandatangani, maka kredit dapat langsung menggunakan dasar grosse akta pengakuan hutang sebagai dasar permohonan paksa badan.

\section{Akibat Hukum Paksa Badan}

Paksa badan bertujuan untuk memaksa debitur memenuhi kewajiban melunasi hutangnya. Debitur atau penjamin hutang sebenarnya mempunyai kemampuan untuk melunasi hutangnya hanya saja debitur tersebut beriktikad tidak baik seolah-olah tidak memiliki harta lagi yang dapat dipakai sebagai sumber pengembalian hutang. Karena itu dengan memasukkan debitur ke rumah tahanan Negara merupakan paksaan bagi debitur agar menyadari dirinya dan kemudian hari hatinya tergerak untuk memenuhi kewajiban pokoknya membayar hutangnya dengan menjual harta kekayaannya atau mengeluarkan uang simpanannya yang tidak diketahui kreditur.

Paksa badan dilakukan dengan cara memasukkan debitur atau panjamin kedalam rumah tahanan Negara, ini berarti mengurangi kebebasan debitur untuk berbuat sesuatu, hak azasi yang bersangkutan dikekang dan dikurangi sebagai imbalan karena tidak melunasi hutangnya. Apabila debitur atau penjamin atau penanggung hutang melunasi hutangnya, maka hak asasi debitur dipulihkan kembali dengan mengeluarkan atau membebaskan yang bersangkutan dari rumah tahanan Negara.

Debitur atau penjamin atau penanggung hutang yang telah menjalani paksa badan tidak berakibat hutangnya menjadi lunas, paksa badan tidak menjadi pengganti pembayaran hutang. Dengan kata lain debitur harus tetap berkewajiban membayar hutang atau melunasi hutangnya meskipun debitur telah menjalani paksa badan karena paksa badan merupakan cara untuk melaksanakan putusan pengadilan untuk memaksa secara tidak langsung agar debitur melaksanakan keputusan pengadilan yaitu membayar hutangnya kepada kreditur sebagai penggugat.

Lamanya paksa badan terbatas jangka waktunya yaitu ditetapkan 6 bulan lamanya dan dapat diperpanjang setiap 6 bulan dengan keseluruhan selama 3 tahun debitur yang menjalani paksa badan tersebut tetap tidak melunasi hutangnya, undang-undang tidak menjelaskan akibat hukumnya, 
menurut pendapat Sutarno, debitur atau penjamin yang telah menjalani paksa badan selama 3 tahun tetap tidak membayar hutangnya, maka debitur atau penjamin hutang tersebut harus dibebaskan dari paksa badan (dikeluarkan dari rumah tahanan). Kreditur harus tetap berusaha dengan cara lain untuk mengeksekusi keputusan pengadilan atau berdasarkan grosse akta pengakuan hutang dengan cara mencari atau menginvestasi harta kekayaan debitur atau penjamin hutang harus dilakukan secara terus menerus atau berkesinambungan sampai hutang debitur dapat dilunasi bahkan jika perlu sampai ahli warisnya jika debitur meninggal. ${ }^{9}$

\section{Analisis Hukum Islam tentang Kredit}

Transaksi hutang piutang dapat terlaksana dengan kerelaan dan amal shalih. Islam mengakui perlunya hutang piutang untuk memenuh kebutuhan debitur, karena seruan perlunya hal ini ditunjukkan dengan adanya anjuran untuk bersikap sosial yang penuh kasih sayang. ${ }^{10}$

Kredit dalam hukum perdata merupakan perjanjian pinjam meminjam uang antara bank sebagai kreditur dengan nasabah sebagai debitur. Sebagai pemberi kredit, bank percaya terhadap nasabahnya dalam jangka waktu yang telah disepakati hutangnya akan dikembalikan lunas. ${ }^{11} \mathrm{Hal}$ ini tentunya tidak jauh berbeda dengan pengertian hutang dalam hukum Islam yang berarti memberikan sesuatu pada seseorang dengan perjanjian dia akan membayarnya yang sama dengan itu. ${ }^{12}$

Akan tetapi kredit dalam perdata, pelunasannya menggunakan bunga, sedangkan dalam hukum Islam, bunga (termasuk) riba. Sedangkan tujuan dari bank konvensional mencairkan kreditnya untuk mendapatkan hasil yang tinggi dari pemberian kredit tersebut. Sedangkan hukum Islam menganjurkan hutang piutang itu dengan tujuan untuk saling menolong dalam hal kebajikan. Bahkan hukumnya bisa menjadi wajib jika orang berhutang itu benar-benar memerlukannya, sebab jika tidak diberikan pinjaman itu, misalnya ia akan menjadi terlantar. Dan haram hukumnya

9 Sutarno, Aspek-aspek Hukum Perkreditan pada Bank, (Bandung : PT Refika Aditama, 2002), hlm.334-340.

${ }^{10}$ Abu Sura'i Abdul Hadi, Bunga Bank dalam Islam, Terjemah M.Tholib. (Jakarta : Gema Insani Press, 2001), hlm. 125

11 Gatot Suparmono, Perbankan dan Masalah Kredit : Suatu Tinjauan Yuridis, (Jakarta : Alvabet, 2009), hlm. 44

12 Sudrsono, Pokok-Pokok Hukum Islam, MKDU, (Bandung : PT. Refika Aditama, 2002), hlm. 414

308 JURNAL LISAN AL-HAL 
jika hutang tersebut digunakan untuk kemaksiatan, sedangkan yang berhutang (debitur) hukumnya mubah. ${ }^{13}$

Apabila berhutang tidak melakukan apa saja yang dijanjikannya, maka ia dikatakan melakukan "wanprestasi" ia alpa atau lalai atau ingkar janji atau juga ia melanggar perjanjian. Bila ia melakukan atau berbuat sesuatu yang tidak boleh dilakukannya, karena dalam hukum Islam debitur yang berniat untuk membayar tetap pada waktunya dan mengusahakan memenuhi janjinya pada waktunya adalah juga berpahala. ${ }^{14}$ Keharusan kedua belah pihak untuk menepati perjanjiannya akan dapat mewujudkan kemantapan dalam bermuamalah. Menghilangkan perselisihan dan memberikan kesempatan pada debitur untuk memanfaatkan barang pinjamannya sehingga terpenuhilah keperluannya.

Dalam hal pengembalian hutang dengan baik adalah membayarnya lebih baik dari pada hutangnya, baik secara kualitatif maupun secara kuantitatif, misalnya: melebihkan bayaran apabila kelebihan bayaran itu atas kemampuan yang berhutang dan tidak atas perjanjian sebelumnya, maka kelebihan itu boleh bagi yang menghutangkan dan bagi yang membayar hutang adalah suatu kebajikan. ${ }^{15}$ Karena hal ini diibaratkan debitur memberi hadiah kepada kreditur tanpa syarat, sesudah hutangnya lunas. Bahkan jika melunasi hutang dengan baik dibolehkan, maka memberi hadiah sesudah lunasnya hutang adalah hal yang lebih baik.

\section{Perspektif Hukum Islam tentang Kredit Macet dalam Hukum Perdata}

Debitur yang tidak mampu memenuhi kewajibannya dalam hukum Islam disebut dengan taflis, menurut ibnu Rusydy taflis terbagi menjadi dua, pertama; apabila hutang itu menghabiskan harta orang yang berhutang sehingga hartanya tidak sanggup lagi untuk melunasi hutangnya, kedua; jika seseorang itu sama sekali tidak mempunyai harta yang konkrit.

Kebangkrutan dari debitur tersebut bisa saja dari salah penggunaan kredit yang telah diberikan oleh pihak bank, atau nasabah kurang mampu mengelola usahanya. Hal ini dapat terjadi kepada nasabah yang kurang mampu menguasai bidang usahanya.

13 Ibid, h. 419

14 Hasbullah Bakry, Pedoman Islam di Indonesia, (Jakarta : Gema Insani Press, 2008), hlm. 288

15 Sudarsono, Pokok-pokok Hukum Islam, MKDU, (Bandung : PT. Refika Aditama, 2002), hlm. 421

JURNAL LISAN AL-HAL $\mid 309$ 
Para ulama' fikih sepakat memberi wewenang kepada hakim untuk melakukan intervensi terhadap sisa harta dari debitur untuk menyelesaikan hutangnya. Menurut ulama' Maliki, Syafi'i dan Hanbali; apabila hakim berpendapat bahwa orang pailit itu dalam kesulitan, maka pemberi hutang tidak boleh menuntutnya dan mengawasinya secara terus menerus. Menurut mereka orang pailit seperti ini dibebaskan mencari rezeki sampai dia berkelapangan untuk membayarnya, sesuai dengan firman Allah SWT dalam surat al-Baqorah ayat 280, yang artinya "dan jika (orang yang berhutang itu) dalam kesukaran, Maka berilah tangguh sampai Dia berkelapangan. dan menyedekahkan (sebagian atau semua utang) itu, lebih baik bagimu, jika kamu mengetahui".

Pada debitur yang tidak mampu membayar hutangnya secara berangsur-angsur atau kontan, walaupun sebelumnya telah berikhtiar sungguh-sungguh untuk membayarnya, maka dalam Islam, kepada kreditur dianjurkan untuk menshadaqahkan sebagian atau semuanya. Hal demikian ini dalam rangka atau salah satu cara untuk menyelesaikan kredit macet, dimana shadaqah yang dilakukan sebagian atau semuanya (al-ibra'), yang berarti mengikhlaskan. Yang hal ini (penghapusan hutang) dalam istilah ilmu fikih berarti pengguguran hutang.

Namun dalam praktiknya, sering terjadi bahwa debitur yang dikalahkan atau tahu akan dikalahkan dalam proses pengadilan, jauh sebelumnya telah mengalihkan harta kekayaannya kepada saudaranya atau orang lain dengan maksud untuk menghindarkan harta kekayaannya tersebut dari penyitaan. Dengan demikian maka secara formil debitur tampaknya sebagai orang miskin, tetapi secara materiil tidak dapat dikatakan demikian.

Untuk kreteria debitur yang semacam ini hukum Islam menerapkan penahanan sebagai hukuman yang pantas bagi debitur yang mampu membayar hutang tetapi menangguhkan pembayaran atau beriktikad tidak baik dengan berpura-pura menjadi miskin, karena menangguhkan pembayaran bagi yang mampu membayarnya adalah suatu kedhaliman.

Para fuqaha juga sependapat, bahwa apabila orang yang berhutang itu mengaku pailit tanpa diketahui kebenaran pengakuannya, maka ia dipenjarakan hingga nyata kebenarannya, dan ia mau melunasinya.

Semua fuqaha sepakat bahwa orang yang berhutang yang enggan untuk melunasinya harus ditahan, karena penahanan tersebut merupakan suatu keharusan, agar manusia itu saling memenuhi hak-hak di antara mereka.

Adapun lamanya debitur disandera, menurut ulama' Hanafi, debitur ditahan untuk jangka waktu 2 bulan atau 3 bulan bila mana terbukti

310 JURNAL LISAN AL-HAL 
bahwa debitur tersebut menyepelekan pembayaran hutangnya, maka penyanderaannya diteruskan sampai dia mau memenuhinya, tetapi bila mana terbukti ia dalam kesulitan, maka debitur tersebut harus mendapat pelepasan.

\section{Simpulan}

Penyelesaian kredit macet dengan Gijzeling menurut hukum perdata ditujukan kepada para debitur yang mampu tetapi enggan untuk melunasi kreditnya. Hutang debitur sedikit-dikitnya 1 miliar keatas (pokok dan bunga), maka kreditur atau bank yang menganjurkan paksa badan menanggung biaya selama debitur atau penjamin atau penanggung menjalani paksa badan, paksa badan ditetapkan 6 bulan lamanya dan dapat diperpanjang 6 bulan dengan keseluruhan maksimal 3 tahun.

Sedangkan akibat hukum terhadap debitur setelah adanya Gijzeling, undang-undang tidak menjelaskan akibat hukumnya, namun debitur atau peminjam yang telah menjalani paksa badan selama 3 tahun tetap tidak membayar hutangnya, maka debitur atau penjamin tersebut harus dibebaskan dari paksa badan.

Dengan begitu kreditur harus tetap mencari solusi atau berusaha dengan cara lain untuk mengeksekusi keputusan pengadilan atau berdasarkan grosse akta pengakuan hutang dengan cara mencari atau menginvestasikan harta kekayaan debitur untuk meletakkan sita eksekusi dan kemudian dilakukan pelelangan, pencarian, atau investasi harta kekayaan debitur atau penjamin hutang harus dilakukan secara terus menerus atau berkesinambungan sampai hutang debitur dapat dilunasi bahkan jika perlu sampai pada ahli warisnya jika meninggal.

Menurut hukum Islam penyelesaian kredit macet dengan cara Gijzeling sudah sesuai jika diterapkan bagi debitur yang nakal. Karena debitur yang nakal yang mampu membayar hutangnya tetapi dia lalai merupakan kedholiman dan hukuman yang cocok adalah penahanan. Adapun untuk debitur yang benar-benar memang tidak mampu untuk membayar, jumhur ulama' berpendapat debitur tersebut dilepaskan dari penahanan setelah ada bukti-bukti yang kuat tentang ketidakmampuannya.

\section{DAFTAR PUSATAKA}

Abdul Hadi, Abu Sura'i, Bunga Bank dalam Islam, Terjemah M.Tholib, Jakarta : Gema Insani Press, 2001

Asikin, Zainal, Pokok Hukum Perbankan di Indonesia, Jakarta : Gema Insani Press, 2010 
Bakry, Hasbullah, Pedoman Islam di Indonesia, Jakarta : Gema Insani Press, 2008

Departemen Agama RI, Al-Qur'an dan Terjemahannya, Bandung : CV Penerbit Diponegoro, 2008

Kian Gie, Kwik, Praktik Bisnis dan Orientasi Ekonomi Indonesia, Jakarta : Kencana, 2006.

Mertokusumo, Sudikno, Hukum Acara Perdata Indonesia, Surabaya : CV Putra Media Nusantara \& ITSPress, 2009

R. Soesilo, RIB/HIR dengan Penjelasannya, Bogor : Politera,1984

Sudarsono, Pokok-Pokok Hukum Islam, MKDU, Bandung : PT. Refika Aditama, 2002.

Suharmo, Aspek-aspek Hukum Perkreditan pada Bank, Jakarta : PT. Raja Grafindo Persada, 2009

Suparmono, Gatot, Perbankan dan Masalah Kredit : Suatu Tinjauan Yuridis, Jakarta : Alvabet, 2009.

Sutarno, Aspek-aspek Hukum Perkreditan pada Bank, Bandung : PT Refika Aditama, 2002 